\title{
"Footprint": The Apocalyptic Imprint of End as Immanent in Atwood's Oryx and Crake
}

\author{
Denise B. Dillon
}

James Cook University Singapore

\begin{abstract}
In her speculative fiction novel, Oryx and Crake, Atwood explores and challenges readers with visions of loss: the extinction of life forms, of culture, and loss of human control over various systems including those of language, economy and ecology. All such systems are prone to human manipulative influence and sensitive to minor alterations that result in major disruptions and ultimately to extinction, disappearance (both forms of loss) or, at best, altered forms of survival. I consider here McKibben's suggestion that we live in a "postnatural world" because human activity has altered things as fundamental as the weather, and explore Atwood's depiction of some of the consequences of a human-altered future in which a great city transforms into a harsh, tropical wilderness. I also apply Buell's notion that apocalyptic rhetoric serves to alert people to global environmental threats by arousing their imagination to a "sense of crisis," through this "master metaphor". If only perceptions to threats are sufficiently aroused such that people are spurred to action, real apocalypse might thereby be delayed. Buell expresses the view that the environmental imagination has a sure role in how people might be able to adapt to transformations in the environment by gaining understanding of what the human relation to nature can be and what it should be. The notion of apocalypse is a strong and enduring theme in literature and is of particular relevance to speculative fiction pertaining to human desire to exercise ultimate control, as is Oryx and Crake.
\end{abstract}

Keywords: apocalyptic rhetoric; ecocriticism; environmental imagination; tropical cities in literature 
On the eastern horizon there's a greyish haze, lit now with a rosy, deadly glow. Strange how that colour still seems tender. He gazes at it with rapture; there is no other word for it. Rapture. ${ }^{1}$

From this the poem springs: that we live in a place That is not our own and, much more, not ourselves And hard it is in spite of blazoned days. ${ }^{2}$

I $\mathrm{n}$ her speculative fiction novel, Atwood explores and challenges readers with ideas about loss: the extinction of life forms, of culture, and loss of human control over various systems including those of language, economy and ecology. All such systems are prone to human manipulative influence and all are sensitive to minor alterations that result in major disruptions and ultimately to extinction, disappearance (both forms of loss) or, at best, altered forms of survival. I consider here McKibben's suggestion that we live in a "postnatural world" because human activity has altered things as fundamental as the weather (1989/2006, p. 60). In Oryx and Crake, Atwood explores this notion of a human-altered future and explained her stance pertaining to her fictional genre in a 2005 Guardian article:

We want wisdom. We want hope. We want to be good. Therefore we sometimes tell ourselves warning stories that deal with the darker side of some of our other wants. As William Blake noted long ago, the human imagination drives the world. At first it drove only the human world, which was once very small in comparison to the huge and powerful natural world around it. Now we're close to being in control of everything except earthquakes and the weather. (Atwood, 2005)

Not everyone would agree with Atwood about the element of being in control and indeed she herself appears to question to what extent humans can claim to be in ultimate control of the natural world. Further to this end, her novel portrays an apocalyptic vision that culminates in loss but at once also suspends a sense of ending so that the "end" remains as when the novel begins, immanent but not imminent (Kermode, 1966/2000). For his part, McKibben (1989/2006) expressed a more doubtful view of the human command over nature:

Simply because it bears our mark doesn't mean we can control it. This new "nature" may not be predictably violent. It won't be predictably anything, and therefore it will take us a very long time to work out our

\footnotetext{
${ }^{1}$ Atwood, 2003/2013, p. 429.

2 Stephens, 1954/2008, "Notes Towards a Supreme Fiction," p. 383.
} 
relationship with it, if we ever do. The salient characteristic of this new nature is its unpredictability, just as the salient feature of the old nature was its utter dependability. (p. 96)

McKibben here refers to the demise of what we once knew (or thought we knew) as "nature." While we can still detect and witness naturally occurring processes such as rain, wind and heat, we can no longer apply long-term, global forecasts based on "nature's promise" of rationality and expectedness in our universe (p. 99). This is to say that human activities have altered the Earth's climate but humans are not in control of the alterations.

Atwood's protagonist, Snowman, a lone human survivor of a virulent viral outbreak that has all but wiped out humankind, takes to the trees in his accommodation to an outdoors existence that is not readily conducive to life as he knows it. His previous existence was of middle-class city life on the edge of privilege and outsider status (between the upperclass compounds and the pleeblands of the lower classes). The first and final chapters of the novel begin with the same setting and actions so that Snowman's existence is an analogy for both individual narrative and human evolution. Having no sense of life beginning or ending, we begin and end life in medias res, with an ending of life only ever immanent (Kermode, 1966/2000). In Snowman's waking before dawn, motionless and listening to the rhythmic wave-wash of the tide, "the rhythm of heartbeat", we find a human in a naive and vulnerable state, who wants to remain asleep (indeed, he wants to believe in his own state of unawareness) but can no longer ignore his plight. The footprint at zero hour is the imprint of human existence as a deviation from nature so that Snowman's return to the trees might at least indicate a reduction of this human footprint (the ecological demand of the human species on the planet Earth). The human desire to control or subordinate nature stems at least in part from the Biblical notion of man's dominion over other creatures and the subjugation of the Earth to human needs and wants. Another Biblical notion relates to the uncovering of truth, of revelation. One form of revelation is the apocalypse, and this has come to be commonly associated with the end of the world (Kermode). Snowman's rapturous vision in the final chapter (the "final chapter" itself another metaphorical allusion to "the end") further enforces an apocalypse theme, with rapture associated with the transportation of the faithful to heaven before the final tribulation.

Atwood's novel addresses the theme of apocalypse in a way that fits a fin de siècle typecasting, which originally indicated an end of an epoch rather than a world ending. However, Kermode notes that the moods exemplified in fin de siècle phenomena are perpetual (p. 98) and so not strictly limited to millennial cycles, and Oryx and Crake is alive with representative moods of ennui and cynicism paired with a belief in (and evidence of) a once-thriving city alive with technology-derived decadence. Apocalyptic rhetoric, says Buell, serves to alert people to global environmental threats by arousing 
their imagination to a "sense of crisis," through this "master metaphor" (1995, p. 285). If only perceptions to threats are sufficiently aroused such that people are spurred to action, real apocalypse might thereby be delayed. Buell expresses the view that the environmental imagination has a sure role in how people might be able to adapt to transformations in the environment by gaining understanding of what the human relation to nature can be and what it should be. At this juncture it becomes clear that the notion of apocalypse is a strong and enduring theme in literature and of particular relevance to speculative fiction pertaining to human desire to exercise ultimate control, as is Oryx and Crake.

Using the poetry of Yeats as his source, Kermode (1966/2000, p. 99) identified five basic elements of the apocalyptic paradigm: 1. Terrors, 2. Clerkly scepticism of a learned aristocrat, 3. Deep conviction of decadence, 4. Prophetic confidence of renovation, 5. Belief that this moment represents the extreme crisis. Narrowing the field to the environmental imagination, Buell (1995, p. 305) identified four modes of perception that are subsidiary to a sense of imminent environmental peril. These modes of perception are interrelatedness, biotic egalitarianism, magnification of scale, and conflation. In Oryx and Crake terrors are apparent in the fear and outrage in response to bioengineered outcomes such as human tissues, including neocortex, implanted in a transgenic pig host and a chicken base form used to grow chicken parts. Against the obvious pride of those who bioengineered these achievements, these examples are described as immoral and sacrilegious (Atwood, 2003, p. 64) and nightmarish (p. 238) respectively, and the reader is prompted to question along with Jimmy (a.k.a. Snowman) where the line might have been crossed: "How much is too much? How far is too far" (p. 242)? Mary Shelley, author of Frankenstein, recognized such responses would ensue in reaction to human attempts to create life: "for supremely frightful would be the effect of any human endeavour to mock the stupendous mechanism of the Creator of the world" (1831/1969, p. 9). This terrorladen scenario is one that man continues to enact and that "puts us forever into the deity business" (McKibben, 1989/2006). In employing these notions of horror-inducing control over erstwhile natural processes, Atwood stimulates one's environmental imagination so that we are able to more readily understand some of the possible consequences of what McKibben only proposed as potential (e.g. he describes the idea of a chicken as a carcass hooked to a tube p. 167). At the same time, McKibben (and Atwood through her speculative fiction) warn that engaging in such creation would represent the "second end of nature" (p. 166), by which McKibben means purposefully indiscriminate creation of artificial life forms. This leads us to Kermode's second apocalyptic element.

Clerkly scepticism of the learned aristocrat can be found in Oryx and Crake in the eponymous character, Crake, a bioengineering genius who is described as being "intellectually honourable" (Atwood, 2003, p. 79) and suave (p. 243), around whom people smiled deferentially (p. 351). Ultimately, Crake is cynical and he adopts a stance of economic rationalism, which embraces "faith in the beneficence of unfettered, or 
almost unfettered, market forces" (Manne, as qtd in Whitwell, 2014). Through his free cities project, Melián (2011) describes the idea of the free market, rather than the government, as "the most efficient mechanism by which individuals choose what they think can satisfy their needs". In his landmark essay, "The use of knowledge in society," Hayek (1945) addresses an assumptive solution to the task of constructing rational economic order:

On certain familiar assumptions the answer is simple enough. If we possess all the relevant information, if we can start out from a given system of preferences and if we command complete knowledge of available means, the problem which remains is purely one of logic. That is, the answer to the question of what is the best use of available means is implicit in our assumptions. (p. 519)

Atwood highlights the matter of logic in various contrasts between science and the arts. For instance, Crake progresses to the Watson-Crick Institute (tellingly named after scientists who first described the DNA structure) and Jimmy to the Martha Graham Academy, "named after some gory old dance goddess of the twentieth century" (218). Jimmy feels the need to defend the arts against what he considers to be Crake's outrageously misanthropic claims, and Crake responds to Jimmy's jibe about Crake not believing in God: "I don't believe in Nature either. Or not with a capital N (Atwood, 2003, p. 242)." Nevertheless, the science-arts divide is not always clearly demarcated. For instance, Oryx (a young woman whom Jimmy and Crake initially came across while browsing kiddy porn sites and who becomes Jimmy's lover) explains to Jimmy that "Crake lives in a higher world... a world of ideas" (p. 368), which is arguably in the domain of arts rather than science. Jimmy claims the realm of ideas as his own and resents it when Crake "poaches" on his "shoddy, threadbare territory" (p. 196).

Conversations between Jimmy and Crake in their formative years cast Jimmy as representing ars poetica as a foil for Crake as ars technê, but the trio can also be taken as a representative contrast between Crake's logos and Oryx's ethos against Snowman's pathos. In his Paradice project, Crake plays with the building blocks of life while Jimmy's games involve words. Crake targets overpopulation in the overcrowded cities of the future as the cause of environmental degradation and poor nutrition, and thus justifies the development of the BlyssPluss Pill as a carefully designed remedy to external causes of death, such as war, contagious diseases, and overpopulation. Despite the intention to give the "human race a better chance of swimming", it is difficult to align Crake's view with latter events whereby the human race is largely wiped out and survived by Crake's legacy, the Crakers. Wallace (2000) quotes Latour's explanation of the replacement of socialism with capitalism: "By seeking to reorient man's exploitation of man toward an exploitation of nature by man, capitalism magnified both beyond measure" (p. 145). This magnification through capitalism is represented in the novel through a separation of those 
in the pleeblands, where everything is subject to chance (Atwood, 2003, p. 231) and the carefully controlled, security-guarded compounds in which the scientists reside and accomplish their work, which is essentially the exploitation of the building blocks of life for financial gain.

Speaking of postmodern ecology, Wallace (2000) cautions that "...capitalism appears to be a veritable law of nature" (p. 152) and we might qualify this by speaking instead of a postnatural ecology. While some are inclined to believe well of humankind's capacity for moderation, McKibben (1989/2006) finds it difficult to believe that we would decide to use genetic engineering technology sparingly and only for purposes such as medical beneficence. Human nature is such that we are just as likely to apply such technologies to marketable ends such as "to straighten trees or grow giant trout" (McKibben, p. 194), activities which are already in play in the present time. In the novel, Crake describes a hypothetical scenario in which a health company uses illnesses to create a commodity through the "economics of scarcity", by developing diseases that cause lingering illnesses (Atwood, 2003, pp. 246-248). While Crake does not admit to any firm agreement with such rationalism, his later activities towards overcoming "[g]rief in the face of inevitable death" (p. 347) through development of the prophylactic BlyssPluss Pill align him with this philosophy. Crake's misanthropic scepticism leads him to develop the Pill, designed with the primary intention of reducing the human population while allowing their continued indulgence in promiscuous behaviour (p. 347).

Atwood's conviction of decadence further comes across in the descriptions of characters who avail themselves of an array of websites showing ethically questionable content. These range from the relatively benign Noodie News with naked news commentators, to Felicia's Frog Squash showing such actions as a frog being stomped or a cat being torn apart by hand (Atwood, 2003, pp. 93-94), and further to executions in places like China or the Middle East. Other sites show electrocutions, lethal injections, assisted suicide, 24-hour voyeurism, and porn (pp. 96-97) and exposure to all of these under drug-induced highs leaves character Jimmy feeling "as if he'd been to an orgy, one at which he'd had no control at all over what had happened to him" (p. 99). It is common, says Kermode, to combine a sense of social decadence with technological utopianism (p. 100), and we see in the novel all manner of technological advances that are all the more greatly appreciated in their absence, in the post-apocalyptic aftermath through which the urban jungle of an erstwhile temperate climate city becomes a harsh, tropical jungle alive with genetically modified species. Just as Crake's development of the pill was intended to use human nature against its own decadent desires, so was his "life's work" intended as a foil for human foibles.

In the ethnogenesis of a new species of people, the Crakers, Crake represents the prophetic confidence of renovation or renewal. Populations of this new species could be created with specially selected characteristics and with undesirable characteristics 
engineered out of the gene pool. Thus we see that here we have renewal with a twist, from a biotechnological point of view whereby the organism is no longer a discrete entity but instead a few lines of code which makes nature nothing more than a sphere of computational influence (McKibben, 1989/2006, pp. 168-169). Despite the new species being able to reproduce through "natural" means, they are genetically mapped with various "improvements" upon the human species. Crake's confidence of renovation and renewal is such that he deems the genetically engineered outcomes as more important than the process (Atwood, 2003, p. 235) so that these new versions belong to a realm where nature has few limits. We might be tempted to believe that natural limits are only bound by the confines and capacity of human perception and therefore are meant to be tested. After all, even the noted British physicist Stephen Hawking (2014) discussed Einstein's dissatisfaction with the apparent randomness in nature but noted that experimental tests of hidden variables showed inconsistencies ("Does God Play Dice?"):

Thus it seems that even God is bound by the Uncertainty Principle, and can not know both the position, and the speed, of a particle. So God does play dice with the universe. All the evidence points to him being an inveterate gambler, who throws the dice on every possible occasion.

Nevertheless, attempts to imitate God lead us back to the question of morality and a sense of unease so, in this sense, renovation and renewal themes are underscored with terror of the unknown and of what might be considered the arrogance of Man's overreaching into deistic activities.

As for belief that ours is the extreme crisis, there is some indication that circumstances in the world as portrayed in the novel are dire, such as Texas drying up and blowing away (Atwood, 2003, p. 287), and cities being inundated (e.g. Harvard being drowned) (p. 203). We learn that the weather has changed to the extent that winters are now warm even in February (when twisters are not now uncommon) and June is a "wet season all the way up the east coast" (p. 203), during which there are thunderstorms. It is now so hot in Canada that the protagonist, Snowman, will burn within a few minutes of being out in the sun (p. 328), "despite the sunblock and the two layers of cloth" (p. 333). As to potential causes, these might come from the same list as that provided to players of an online game in which they selected "what had snuffed" a species: "Pollution, habitat destruction, credulous morons who thought that eating its horn would give them a boner" (p. 92). These instances of climate change serve to iterate McKibbens' (1989/2006) claim that not only species, but also natural processes, are subject to extinction (p. 59). The seasons of seasons past are not the seasons of seasons future, and not just in temporal form; they have been altered but are not by any means under control. Of course, Kermode (1966/2000) reminds us that all crisis moments are ends and beginnings and so we are readily convinced that ours is the crisis in extremity (p. 96). 
Crises are indeed our perceptions of certain moments rather than moments being critical in and of themselves. Nonetheless, readers' perceptions of the crisis portrayed in the novel are allowed free reign through Atwood's carefully unbiased intrusion on the decision-making process. She adopts an ethnographic-like approach to the narrative in field-report style performed by an omniscient narrator, the ethnographer. In addition to what we might reasonably accept as field reports about the culture and society in which her characters were raised we also learn about the circumstances leading up to the viral outbreak that ultimately wipes out most of humankind. Another consequence of the absence of human controllers is that human-made animal-like bioforms contrived such that they need to be contained (because dangerous) are released into the environment. The viral outbreak is the extreme crisis-inducing event after which "the whole world is now one vast uncontrolled experiment....and the doctrine of unintended consequences is in full spate" (Atwood, 2003, p. 267). The crisis moment of viral epidemic is replaced with the ongoing crisis for Snowman in finding ways to adapt and survive in this new world in which he is at once teacher and protector of the Crakers and prey for the newly released bioforms including pigoons and wolvogs.

We can thus see that Atwood's speculations concerning an imaginatively conceived yet foreseeable future are imbued with these various apocalyptic elements. Conversely, although we get a sense of imminent environmental peril (e.g., references to weather systems that are altered due to climate change and global warming), biotic egalitarianism is starkly absent in the novel and, despite her otherwise seemingly unbiased stance, perhaps Atwood offers a message that this absence must not continue. In her reporting of various weather-related phenomena Atwood conflates actual global reports, projections and predictions over many years and also thus influences readers' perceptions of our world in crisis. Imaginative thinking is the keystone to creativity, and creativity is itself the keystone to actualisation. Crake recounts as amazing the "onceunimaginable things" that his team had achieved (Atwood, 2003, p. 358), and Atwood contrasts science and art (e.g., ars techne in Crake's Logos vs. ars poetica in Snowman's Pathos) throughout to show that in this world of created nature, science has been privileged over the arts. It is perhaps herein where Atwood sees the root of the environmental crisis, in the exhaustion of the arts through repeated degradation and loss of power. "Increasingly, if we can imagine it, we'll be able to do it," says Atwood (2005, n.p.), and indeed the novel is infused with instances of technological achievements that have already progressed beyond the imagination. Examples include the gene-spliced spoat/gider ("goat crossed with spider to produce high-tensile spider silk filaments in the milk" Atwood, 2003, p. 234), luminescent plants, and the Happicuppa coffee bush, "designed so that all of its beans would ripen simultaneously" (p. 210). Nonetheless, despite substantive evidence that humans have made an indelible and detrimental mark on the natural world, an optimistic outlook is still possible in light of the substantial and wonderful power of the imagination. 
Human perceptions allow us to assimilate and accommodate to changing environments so that our notions of "nature" and "wild" can exist in our minds and are thus durable even while actual environments are degraded (McKibben, 1989/2006, p. 58). While this ability is useful for retention of a positive outlook on life, it is also deeply disturbing at some level to understand that perceptions might change across time for those in whose lifetime nature and wild are merely imagined, and so on for future generations. Amidst his descriptions of the human-fashioned postnatural world, McKibben reminds us that he (and we) can still imagine a world of reduced reliance on technology: "Possession of a certain technology imposes on us no duty to use it" (p. 194). Such ideals fit with the pastoral logic on which environmental apocalypse rests; that is, that a state of existence in which man and nature are not at odds is morally superior to one in which man claims dominion (Buell, 1995, p. 300). Oryx and Crake can thus be read as a cautionary tale, an imaginative warning against what could very readily happen. Writers such as McKibben and Buell amply and ably remind us that the fate of humankind rests on the ability of writers such as Atwood to stir people's imaginations such that a sense of crisis becomes imminent rather than remaining merely immanent.

In the telling incompleteness of the final chapter, Atwood allows her readers to draw their own conclusions as to what will come of Snowman's rapture. We might take it that the world carries on in a dependable way as it has seemingly done for us in our comfort-the ocean's tides at least continue to follow some sort of order, and the wave sounds are soothing in their heartbeat-like consistency at the pre-dawn tide. We reassure ourselves in knowing that our hearts can also still be seized and carried away by the world's beauty and by our own experiences of blazoned days. However, Atwood retains the apocalyptic vision-heartbeats are of course subject to continued living, and Snowman's heart is seemingly seized and carried aloft not by a merciful god, but a large bird of prey. This is, after all, the second end of nature accompanied by "shrieks and cries that sound like nothing human" (Atwood, 2003, p. 429) because, in this world, Man is the creator and the animals are no longer what was formerly known as natural but instead they are humanmade. Despite her claim that humans are now in control of everything except earthquakes and the weather, the circumstances Atwood describes in Oryx and Crake are testament to McKibben's warning that just because humans have changed the world does not mean we control it. Atwood is silent in predictions as to what might happen to the world beyond "Footprint", simply because her predictions are no more or less likely than our own-the world we have created is unpredictable. From our first sight of Snowman in the originating chapter, he appears to us as a cautious tree dweller who comes down from the trees only when all is quiet and there are no "scales or tails" to indicate danger: "Left hand, right foot, right hand, left foot, he makes his way down from the tree." (Atwood, 2003, p. 4). By novel's end, in our now post-apocalyptic awareness we see Snowman as a pathetic figure who questions his lonely existence: "From tree to tree he [Snowman] limps, elusive, white, a rumour. In search of his own kind" (p. 431). The terror-inducing zero hour in the first chapter becomes in the end a humble acknowledgement that his world has changed 
beyond measure and time has indeed run out. In Atwood's fictional work imbued with environmental imagination, Snowman embodies the whimper at world's end.

This is the way the world ends

This is the way the world ends

This is the way the world ends

Not with a bang but a whimper. ${ }^{3}$

\section{References}

Atwood, M. (2003). Oryx and Crake. London: Virago.

Atwood, M. (2005). "Aliens have taken the place of angels" The Guardian, June 2005. Retrieved from

https://www.theguardian.com/film/2005/jun/17/sciencefictionfantasyandhorror.margaretat wood

Buell, L. (1995). The Environmental Imagination: Thoreau, Nature Writing, and the Formation of American Culture. Cambridge, MA: Belknap Press of Harvard University Press.

Hawking, S. (2014). "Does God Play Dice?" Retrieved from http://www.hawking.org.uk/doesgod-play-dice.html

Hayek, F. A. (1945). The use of knowledge in society. The American Economic Review, 34(4), 519-530.

Kermode, F. (1966/2000). The Sense of an Ending: Studies in the Theory of Fiction. Oxford: Oxford University Press.

McKibben, B. (1989/2006). The End of Nature. New York, NY: Random House.

Melián, G. (4 April, 2011). The future of free cities. Retrieved from https://newmedia.ufm.edu/coleccion/the-future-of-free-cities/different-ways-to-design-afree-market-city/

Shelley, M. W. (1831/1969). Frankenstein: Or the Modern Prometheus. London: Oxford U.P.

Stevens, W. (1954/2008). The Collected Poems of Wallace Stevens. New York: Knopf.

Wallace, M. (2000). "A Bizarre Ecology." The nature of denatured nature. Interdisciplinary Studies in Literature and Environment 7(2), 137-153.

Whitwell, G. (2014). Feature - What Is Economic Rationalism? N. p., n.d. Accessed 24 Mar. 2014.

${ }^{3}$ Thomas Stearns Eliot, "The Hollow Men". 